\title{
ANALISIS KEMAMPUAN BERPIKIR REFLEKTIF MATEMATIS SISWA DALAM MENYELESAIKAN SOAL CERITA
}

\author{
Ronauli Sihaloho' ${ }^{1}$, Rafiq Zulkarnaen ${ }^{2}$, Haerudin ${ }^{3}$ \\ 1,2,3 Program Studi Pendidikan Matematika, Universitas Singaperbangsa Karawang \\ email korespondensi : 1610631050133@student.unsika.ac.id
}

Diterima : (15-07-2020), Revisi: (22-10-2020), Diterbitkan : (24-12-2020)

\begin{abstract}
ABSTRAK
Penelitian ini bertujuan untuk menganalisis kemampuan berpikir reflektif matematis (KBRM) siswa dalam menyelesaikan soal cerita. KBRM menggunakan pengetahuan, dan pengalaman yang dimiliki siswa dalam menyelesaikan soal cerita matematika. Metode yang digunakan dalam penelitian ini adalah studi kasus dengan kasus tunggal dan analisis tunggal. Subjek penelitian sebanyak 32 siswa kelas X pada satu SMA Negeri di Kabupaten Karawang, Jawa Barat. Instrumen tes dan non tes digunakan dalam penelitian ini. Instrumen non tes meliputi wawancara dan observasi, sedangkan instrumen tes yang digunakan yaitu empat soal cerita yang berkaitan dengan materi sistem persamaan linier tiga variabel. Hasil jawaban siswa kemudian dikelompokkan kedalam kategori Tinggi, Sedang, dan Rendah serta dianalisis berdasarkan tahapan kemampuan berpikir reflektif matematis dalam aspek reacting, comparing/ elaboration, dan contemplating. Hasil analisis jawaban dan wawancara menunjukkan bahwa kemampuan berpikir reflektif matematis digunakan siswa dalam menyelesaikan soal cerita, namun ketidaktelitian dalam memahami soal, menghubungkan, memberikan kesimpulan, hingga kegigihan siswa, menyebabkan jawaban yang diberikan masih belum tepat.
\end{abstract}

Kata kunci : menanggapi, menghubungkan, menyimpulkan 


\begin{abstract}
This study aims to analyze student's mathematical reflective thinking (MRT) ability in solving word problems. MRT using previos knowledge and experience to solving the problem. The method used in this study is a single case study and a single analysis. The subject sample of this research consists of 10th-grade students at one of senior high school in Karawang, West Java, Indonesia. Test and non-test instruments are used in this study. Non-test instruments covers interviews and observations, andtest instruments are usedis four item word problems relating to systems of linear equations three variables. The results of students' answers are then grouped into high, moderate, low categories, and in reflective thought assessments in aspect reacting, comparing, and contemplating. The result of the study shows that subject was able to do three the steps of reflective thinking, but inaccuracy in understand, associate, providing a conclusionand students' persistence causing the answer to be given is imprecies.
\end{abstract}

Keywords : reacting, comparing, contemplating

\title{
Pendahuluan
}

Matematika dapat dikatakan sebagai salah satu ilmu yang dapat mengembangkan proses berpikir siswa. Penyajian soal matematika dalam bentuk narasi-paragraf disebut dengan soal cerita (Zulkarnaen, 2017). Terdapat tiga aspek yang harus dikuasai siswa dalam menyelesaikan soal cerita matematika, yaitu: aspek bahasa, aspek prasyarat dan aspek terapan (Khasanah \& Sutama, 2015). Aspek bahasa merupakan kemampuan siswa dalam memahami dan menerjemahkan soal, aspek prasyarat merupakan kemampuan siswa mengubah soal cerita menjadi model matematis serta menentukan strategi yang digunakan dalam penyelesaian, dan aspek terapan merupakan kemampuan siswa dalam menerapkan rumus dan melakukan perhitungan yang tepat.

Beberapa penelitian menujukkan bahwa kemampuan siswa dalam menyelesaikan soal cerita masih lemah, yaitu kesulitan siswa dalam menyelesaikan soal cerita yang disebabkan kurangnya pemahaman konsep dan kelancaran prosedursiswa, lemahnya siswa dalam proses matematisasi situasi masalah dalam soal cerita (Zulkarnaen, 2017). Faktor lain yang menjadi penyebab adalah mengabaikan proses mengidentifikasi, menghubungkan atau mengaitkan permasalahan, serta proses penyelesaian secara langsung (Sihaloho \& Zulkarnaen, 2019). Lemahnya siswa dalam menyelesaikan soal cerita sebagaimana dikemukakan, diduga disebabkan oleh lemahnya kemampuan berpikir reflektif matematis siswa. 
Kemampuan berpikir reflektif merupakan penggunaan daya ingat terhadap pengetahuan yang dimiliki sebelumnya, secara gigih untuk memberikan informasi penting, menghubungkan dengan pengalaman pribadi, dan memberikan kesimpulan pada penyelesaian soal yang sedang dihadapi. Kemampuan berpikir reflektif matematis sangat penting guna mengembangkan daya ingat siswa dalam menyelesaikan soal cerita. Kemampuan berpikir reflektif matematis meliputi kemampuan mengamati dan mengenali unsur-unsur penting, mempertimbangkan strategi-strategi dalam menyelesaikan soal, menggunakan pengetahuan dan konsep dalam solusi penyelesaian (Putri \& Mampouw, 2018). Melalui kemampuan berpikir reflektif matematis yang dimiliki, siswa akan senantiasa memiliki kemampuan dalam menyelesaikan soal dengan berbagai sudut pandang (Nuriadin, 2015). Berdasarkan uraian yang telah dikemukakan di atas, penelitian ini difokuskan untuk menganalisis kemampuan berpikir reflektif matematis siswa dalam menyelesaikan soal cerita.

\section{Metode Penelitian}

Studi kasus digunakan dalam penelitian ini, dengan metode kasus tunggal dan analisis tunggal. Subjek penelitian sebanyak 32 siswa kelas X pada satu SMA Negeri di Kabupaten Karawang, Jawa Barat. Instrumen tes dan non tes digunakan dalam penelitian ini. Instrumen non tes berupa wawancara tidak terstruktur, dan empatsoal cerita yang berkaitan dengan materi sistem persamaan linier tiga variabel (SPLTV) digunakan sebagai instrumen tes dalam penelitian. Sebelum diberikan kepada subjek penelitian, instrumen tes terlebih dahulu dilakukan ujicoba untuk mendapatkan kualitas instrumen yang baik. Ujicoba instrumen digunakan untuk mengetahui validitas butir soal, reliabilitas, daya pembeda, dan tingkat kesukaran mengacu Arifin (2016), dengan hasil uji coba instrumen disajikan pada Tabel 1.

Tabel 1 Hasil uji coba instrumen

\begin{tabular}{|c|c|c|c|c|}
\hline Nomor & & & Uji & \\
\hline Soal & Validitas & Reliabilitas & Daya Pembeda & Tingkat Kesukaran \\
\hline 1 & 0,50 (Sedang) & \multirow{4}{*}{ 0,45 (Sedang) } & 0,33 (Sedang) & 0,46 (Sedang) \\
\hline 2 & 0,49 (Sedang) & & 0,43 (SangatBaik) & 0,50 (Sedang) \\
\hline 3 & 0,50 (Sedang) & & 0,50 (SangatBaik) & 0,73 (Mudah) \\
\hline 4 & 0,56 (Sedang) & & 0,36 (Baik) & 0,26 (Sukar) \\
\hline
\end{tabular}

Perolehan skor jawaban siswa terhadap instrumen tes kemampuan berpikir 
reflektif matematis kemudian dikelompokkan kedalam kategoriTinggi, Sedang, dan Rendah. Pengelompokkan siswa pada kategori Tinggi apabila skor yang diperoleh siswa (disingkat, sks) $s k s \geq \bar{x}+s d$, kategori Sedang apabilax $-s d \leq s k s<\bar{x}+$ $s d$, dan kategori Rendah apabila $\bar{x}-s d<s k s$. Selanjutnya, jawaban siswa dianalisis berdasarkan tahapan kemampuan berpikir reflektif menurut Surbeck, Han \& Moyer (Salido, 2019), sebagai berikut: Reacting, yaitu tanggapan awal siswa berdasarkan pemahaman pribadi dengan berfokus pada sifat situasi alami seperti mengidentifikasi soal; Comparing/Elaboration, yaitu memperluas reaksi yang muncul, mencoba menghubungkan atau mengaitkan pemikiran, dan membandingkan yang mengacu pada pemahaman konsep; Contemplating, mengutamakan pengertian pribadi yang mendalam seperti menjelaskan, menguraikan, mempertimbangkan, dan merekonstruksisituasi yang terdapat pada soal sehingga diperoleh suatu kesimpulan.

\section{Hasil dan Pembahasan}

Data pengelompokkan kemampuan berpikir reflektif matematis (KBRM) siswa disajikan pada Tabel 2.

Tabel 2. Perolehan skor KBRM dan pengelompokkannya

\begin{tabular}{cccl}
\hline \multirow{2}{*}{ Kategori } & \multicolumn{2}{c}{ Datastatistik } & \multicolumn{1}{c}{ Identifikasi Siswa } \\
\cline { 2 - 3 } & $\bar{x}$ & \multicolumn{1}{l}{$s d$} & \\
\hline Tinggi & 28,33 & 4,03 & S-1, S-2, S-6, S-8, S-9, S-12,S-21, S-24, S32. \\
\hline \multirow{2}{*}{ Sedang } & 19,57 & 3,32 & $\begin{array}{l}\text { S-3,S-4, S-11, S-13, S-14, S15, S-16, S-18, S-19, S-25, } \\
\text { S-26, S-27, S-28, S-29. }\end{array}$ \\
\hline Rendah & 8,78 & 3,60 & S-5, S-7, S-10, S-17, S-20, S-22, S-23, S-30, S-31. \\
\hline
\end{tabular}

Keterangan: Skor Maksimal Ideal $=36$

Pencapaian siswa dalam menyelesaikan soal cerita siswa masih rendah. Hal ini terlihat dari perbandingan rerata pada masing-masing kelompok (Tinggi, Sedang, dan Rendah) dengan skor maksimal idealnya. Fakta tersebut mengindikasikan bahwa KBRM siswa belum digunakan secara optimal dalam menyelesaikan soal cerita yang diberikan. Siswa memahami soal, namun belum mampu dalam menghubungkan dan memberikan pendapat pada proses penyelesaian, menyebabkan hasil akhir tidak diberikan secara optimal (Suharna, 2018). Untuk mendapatkan gambaran kemampuan berpikir reflektif matematis siswa pada masing-masing kategori sebagaimana disajikan pada Tabel 2 dipilih S-12 dan S-24 
(pada kategori Tinggi), S-14 dan S-16 (pada kategori Sedang), S-17 dan S-30 (pada kategori Rendah).

Soal nomor 1 yang diberikan kepada subjek penelitian, yaitu: "Suatu bilangan terdiri atas tiga angka yang berjumlah 12. Angka satuannya enam lebihnya dari angka puluhan. Jika angka ratusan dan angka puluhan ditukar letaknya, maka diperoleh hasil yang sama. Berdasarkan pernyataan di atas, variabel-variabel apa saja yang kalian temukan? Jelaskan!" Karakteristik jawaban untuk soal nomor 1 disajikan pada Tabel 3.

Tabel 3. Karakteristik Jawaban Siswa untuk Soal Cerita Nomor 1

\begin{tabular}{cl}
\hline Kelompok Siswa & \multicolumn{1}{c}{ Reacting } \\
\hline \multirow{2}{*}{ Tinggi } & $\begin{array}{l}\text { Menjelaskan informasi-informasi yang penting terdapat pada soal, } \\
\text { menyebutkan hubungan diantara unsur yang diketahui dan unsur } \\
\text { ditanyakan yang terkandung dalam soal.Namun, belum menjawab } \\
\text { pertanyaan dengan tepat. }\end{array}$ \\
\hline Sedang & $\begin{array}{l}\text { Menggunakan permisalan untuk menentukan informasi penting yang } \\
\text { terdapat pada soal. Namun, belum menjawab pertanyaan dengan } \\
\text { (S-14 dan S-16) }\end{array}$ \\
\hline \multirow{2}{*}{ Rendah } & $\begin{array}{l}\text { Hanya menyebutkan unsur yang diketahui dan unsur yang ditanyakan } \\
\text { dalam soal, dan belum mampu membuat model matematis dari soal } \\
\text { (S-17 dan S-30) }\end{array}$ \\
\hline
\end{tabular}

Berdasarkan Tabel 3 terlihat bahwa untuk soal cerita nomor 1, siswa pada kelompok Tinggi, Sedang, dan Rendah mampu menentukan unsur yang diketahui dan ditanyakan dalam soal serta menentukan hubungan diantara keduanya. Akan tetapi, tidak ada jawaban yang menunjukkan aspek comparing dan tahap contemplating. Temuan tersebut disebabkan karakteristik soal cerita nomor 1 kurang berkaitan dengan situasi dunia nyata. Karakteristik soal cerita tersebut menyebabkan siswa tidak dapat menghubungkan soal cerita yang diajukan dengan soal SPLTV yang pernah dihadapinya (comparing) yang menyebabkan siswa tidak mampu menentukan maksud dari permasalahan (contemplating).

Berbeda halnya dengan soal cerita nomor 2, 3, dan 4, soal cerita dikemas sedemikian rupa memuat situasi dan konteks dunia nyata. Dari analisa hasil jawaban, menujukkan bahwa KBRM siswa pada aspek comparing dan contemplating digunakan untuk menyelesaikan soal cerita yang diberikan.

Soal nomor 2 yang diberikan kepada subjek penelitian, yaitu: "Bu Pita memiliki tiga jenis rak untuk menyimpan piring. Jumlah piring rak kedua ditambah rak 
tiga adalah 136 dan jumlah rak ketiga 24 kurangnya dari rak pertama. Ketika sedang memasukkan piring kedalam rak pertama, sepertiga piring tersebut jatuh dan pecah, sehingga piring yang ada pada rak pertama dan kedua sama banyaknya. Diberikan dua penyelesaian soal. Manakah jawaban yang benar? Kemukakan alasannya!"

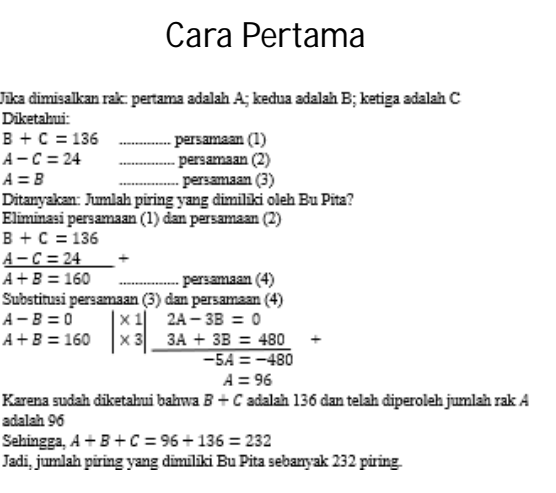

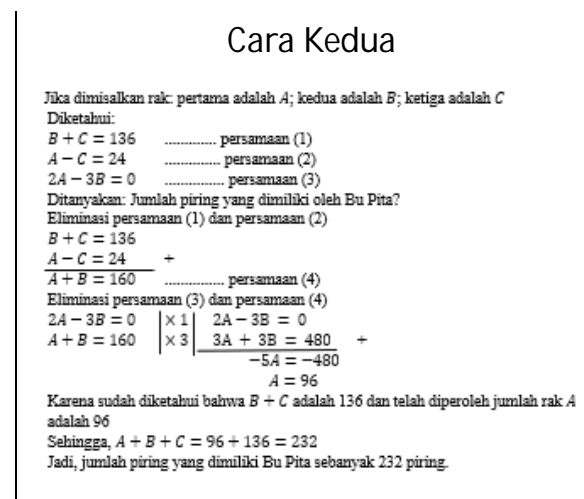

Soal cerita nomor 2 diberikan kepada siswa memuat dua cara penyelesaian, soal ini bertujuan untuk mengetahui aspek analitis siswa dalam menentukan cara penyelesaian mana yang benar atau bahkan keduanya salah. Namun dalam penyelesaiannya siswa tidak menggunakan dua penyelesaian yang telah diberikan untuk dikoreksinya, akan tetapi mayoritas siswa membuat cara sendiri penyelesaian kemudian membandingkan hasilnya dengan cara penyelesaian yang termuat dalam soal. Adapun karakteristik jawaban untuk soal nomor 2 disajikan pada Tabel 4.

Tabel 4. Karakteristik Jawaban Siswa untuk Soal Nomor 2

\begin{tabular}{|c|c|c|}
\hline Kelon & Reacting & Comparing/ Elaboration \\
\hline $\begin{array}{c}\text { Tinggi } \\
\text { (S-12 dan S-24) }\end{array}$ & $\begin{array}{l}\text { Menggunakan permisalan } \\
\text { untuk mempermudah dalam } \\
\text { menyebutkan informasi } \\
\text { penting yang terdapat pada } \\
\text { soal. }\end{array}$ & $\begin{array}{l}\text { Memahami } \\
\text { menyelesaikan soal cerita yang } \\
\text { diberikan, mencoba menyelesaikan } \\
\text { soal kemudian menghubungkan } \\
\text { pernyataan dengan mengaitkan hasil } \\
\text { jawaban yang telah diselesaikan } \\
\text { terlebih dahulu, serta memberikan } \\
\text { alasan terhadap hasil yang diperoleh. }\end{array}$ \\
\hline $\begin{array}{c}\text { Sedang } \\
\text { (S-14 dan S-16) }\end{array}$ & $\begin{array}{l}\text { Menggunakan permisalan } \\
\text { untuk menentukan informasi } \\
\text { penting yang terdapat pada } \\
\text { soal. }\end{array}$ & $\begin{array}{l}\text { Menghubungkan unsur-unsur yang } \\
\text { diketahui dalam soal serta mampu } \\
\text { memberikan alasan meskipun belum } \\
\text { tepat. }\end{array}$ \\
\hline Rendah & Menyebutkan & Menghubungkan dan \\
\hline
\end{tabular}




\begin{tabular}{llll}
\hline Kelompok Siswa & \multicolumn{2}{c}{ Reacting } & \multicolumn{2}{c}{ Comparing/ Elaboration } \\
\hline (S-17 dan S-30) & diketahui dan unsur yang & alasan, namun tindakan yang \\
& ditanyakan dalam soal. & dilakukan dalam menghubungkan \\
& & kedua pernyataan dan alasan yang \\
& & diberikan masih belum tepat. \\
\hline
\end{tabular}

Berdasarkan Tabel 4 siswa pada kelompok Tinggi, Sedang, dan Rendah menggunakan KBRM khususnya tahap reacting dan comparing dalam menyelesaikan soalcerita yang diberikan. Dari hasil analisa jawaban, siswa sudah mampu menyebutkan unsur yang diketahui dan ditanyakan, menentukan strategi penyelesaian, dan memberikan alasan terhadap permasalahan yang diberikan. Namun demikian, siswa belum melakukan tahap contemplating. Hal inidisebabkan oleh kekeliruan siswa dalam memahami kata "kurangnya dari rak pertama" yang termuat dalam soal yang menyebabkan siswa kebingungan dalam memperbaiki dan menjelaskan jika terjadi kesalahan dari jawaban. Berikut merupakan penggalan wawancara pada salah satu subjek dalam menjawab soal nomor 2:

P : "Apa yang ditanyakan pada soal nomor 2?"

S-17: "Cari perbedaan dari dua jawaban mana yang benarnya"

P : "Menurut kamu dari kedua jawaban mana yang benar?"

S-17: "A kak"

P : "Kenapa?"

S-17: Aku juga gak ngerti kak, aku liatnya karena disoal kan udah dikasih tau kalau hasil rak pertama dan kedua jumlahnya sama, makanya aku pilihnya yang A ka karena dipersamaan $3 \mathrm{~A}=\mathrm{B}$ "

Soal cerita nomor 3 yang diberikan kepada subjek penelitian, yaitu: "Pak Karlo memiliki tiga orang anak yaitu Manda, Nau, dan Ucup. Pada tahun 2020 jumlah usia anak Pak Karlo sama dengan 52. Jika usia Ucup dikurangi lima, maka hasilnya sama dengan usia Manda. Jika usia Manda ditambah delapan, maka hasilnya sama dengan usia Nau. (a) Apakah benar lima tahun mendatang usia Manda 24 tahun? Jelaskan! (b) Berapakah masing-masing usia anak Pak Karlo?" Karakteristik jawaban siswa untuk soal cerita nomor 3 disajikan pada Tabel 5.

Tabel 5. Karakteristik Jawaban Siswa untuk Soal Cerita Nomor 3

\begin{tabular}{|c|c|c|c|}
\hline $\begin{array}{c}\text { Kelompok } \\
\text { Siswa }\end{array}$ & Reacting & Comparing/ Elaboration & Contemplating \\
\hline $\begin{array}{l}\text { Tinggi } \\
\text { (S-12 dan } \\
\text { S-24) }\end{array}$ & $\begin{array}{l}\text { Menyebutkan hu- } \\
\text { bungan diantara } \\
\text { unsur yang diketa- }\end{array}$ & $\begin{array}{l}\text { Menggunakan metode } \\
\text { eliminasi dan substitusi } \\
\text { dalam menyelesaikan }\end{array}$ & $\begin{array}{l}\text { Memberikan } \\
\text { kesimpulan yang be- } \\
\text { nar. }\end{array}$ \\
\hline
\end{tabular}




\begin{tabular}{|c|c|c|c|}
\hline $\begin{array}{c}\text { Kelompok } \\
\text { Siswa }\end{array}$ & Reacting & Comparing/ Elaboration & Contemplating \\
\hline & $\begin{array}{l}\text { hui dan ditanyakan } \\
\text { yang terkandung } \\
\text { dalam soal. }\end{array}$ & $\begin{array}{l}\text { soal serta memberikan } \\
\text { alasan tepat terhadap } \\
\text { hasil yang diperoleh. }\end{array}$ & \\
\hline $\begin{array}{l}\text { Sedang } \\
\text { (S-14 dan } \\
\text { S-16) }\end{array}$ & $\begin{array}{l}\text { Menyebutkan } \\
\text { informasi penting } \\
\text { yang terdapat pada } \\
\text { soal. }\end{array}$ & $\begin{array}{l}\text { Menggunakan metode } \\
\text { eliminasi dan substitusi } \\
\text { dalam menyelesaikan } \\
\text { soal serta memberikan } \\
\text { alasan tepat terhadap } \\
\text { hasil yang diperoleh. }\end{array}$ & $\begin{array}{l}\text { Belummampu } \\
\text { memberikan } \\
\text { kesimpulan yang be- } \\
\text { nar. }\end{array}$ \\
\hline $\begin{array}{l}\text { Rendah } \\
\text { (S-17 dan } \\
\text { S-30) }\end{array}$ & $\begin{array}{l}\text { Menyebutkan } \\
\text { informasi penting } \\
\text { yang terdapat pada } \\
\text { soal. }\end{array}$ & $\begin{array}{l}\text { Menggunakan metode } \\
\text { eliminasi dan substitusi } \\
\text { dalam menyelesaikan } \\
\text { soal namun salah dalam } \\
\text { memberikan alasan } \\
\text { terhadap hasil yang } \\
\text { diperoleh. }\end{array}$ & $\begin{array}{l}\text { Belum memberikan } \\
\text { kesimpulan terhadap } \\
\text { proses penyelesaian } \\
\text { yang telah dilakukan. }\end{array}$ \\
\hline
\end{tabular}

Berdasarkan Tabel 5 siswa pada kelompok Tinggi, Sedang, dan Rendah menggunakan KBRM untuk menyelesaikan soal cerita yang diberikan. Tahapan berpikir reflektif untuk aksi (reacting), untuk evaluasi (compairing), dan untuk inkuiri kritis (contemplating) digunakan oleh seluruh siswa untuk menyelesaikan soal cerita yang berkaitan dengan materi SPLTV. Contoh jawaban siswa disajikan pada Gambar 1.

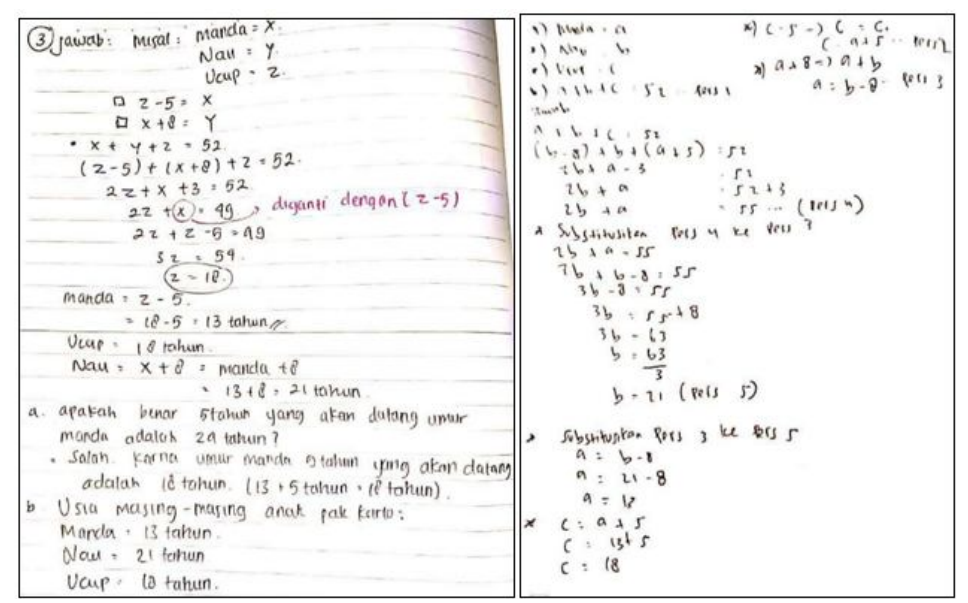

Gambar 1. Contoh Jawaban Siswa S24 dan S30 pada Soal Nomor 3

Berdasarkan Gambar 1, terlihat bahwa subjek S24 pada kelompok Tinggi 
mampu menggunakan pengetahuannya untuk menyelesaikan soal tersebut, sehingga dapat melakukan ketiga tahapan dengan baik. Berbeda dengan subjek pada kelompok Rendah, yang menunjukkan bahwa subjek hanya melakukan proses penyelesaian tanpa menyimpulkan hasil yang telah diperoleh. Hal ini disebabkan oleh kebingungan yang terjadi pada diri siswa dalam menyelesaikan soal. Berikut merupakan penggalan wawancara pada salah satu subjek dalam menjawab soal nomor 3:

$\mathrm{P} \quad$ : “Untuk soal nomor 3, kamu paham maksud pertanyaannya?”

S-30 : "Mencari yang ini kak"

$\mathrm{P} \quad$ : "Apa yang ditanyakan dalam soal?"

S-30 : "Mencari masing-masing usia kak"

$\mathrm{P} \quad$ : “Apa yang kamu lakukan untuk menyelesaikan soal nomor 3?”

S-30 : "Bingung kak"

P : "Kenapa bingung? Ini kamu bisa jawabnya"

S-30 : "Iya kak, tapi itu aku juga bingung kak"

Soal nomor 4 yang diberikan kepada siswa, yaitu: "Teater musikalisasi berlangsung selama dua hari. Teater tersebut dihadiri oleh anak pra-remaja, remaja, dan pemuda. Acara tersebut dapat dihadiri sebanyak 3.000.000 orang. Pada hari pertama 5\% pra-remaja, 6\% remaja, dan 9\% pemuda. Pada hari kedua, banyaknya pra-remaja dan remaja yang hadir sama dengan hari pertama, namun banyaknya pemuda yang hadir berkurang 3\%. Jika pada hari pertama banyaknya pengunjung yang hadir sebanyak 195.000 orang dan pada hari kedua sebanyak 87.000 orang, maka berapakah masing-masing banyaknya pra-remaja, remaja, dan pemuda? Jelaskan metode/ konsep apa yang kalian gunakan!"

Tabel 6. Karakteristik Jawaban Siswa untuk Soal Nomor 4

\begin{tabular}{|c|c|c|c|}
\hline $\begin{array}{c}\text { Kelompok } \\
\text { Siswa }\end{array}$ & Reacting & Comparing/ Elaboration & Contemplating \\
\hline $\begin{array}{l}\text { Tinggi } \\
\text { (S-12 dan } \\
\text { S-24) }\end{array}$ & $\begin{array}{l}\text { Menyebutkan hubungan } \\
\text { diantara unsur yang dike- } \\
\text { tahui dan ditanyakan yang } \\
\text { terkandung dalam soal. }\end{array}$ & $\begin{array}{l}\text { Menggunakan metode } \\
\text { eliminasi dan substitusi } \\
\text { dalam menyelesaikan } \\
\text { soal serta memberikan } \\
\text { alasan tepat terhadap } \\
\text { hasil yang diperoleh. }\end{array}$ & $\begin{array}{l}\text { Memberikan } \\
\text { kesimpulan } \\
\text { yang benar. }\end{array}$ \\
\hline $\begin{array}{l}\text { Sedang } \\
\text { (S-14 dan } \\
\text { S-16) }\end{array}$ & $\begin{array}{l}\text { Menyebutkan hubungan- } \\
\text { diantara unsur yang dike- } \\
\text { tahui dan ditanyakan yang }\end{array}$ & $\begin{array}{l}\text { Menggunakan metode } \\
\text { eliminasi } \\
\text { dan substitusi } \\
\text { dalam menyelesaikan }\end{array}$ & $\begin{array}{l}\text { Belum } \\
\text { memberikan } \\
\text { kesimpulan }\end{array}$ \\
\hline
\end{tabular}




\begin{tabular}{|c|c|c|c|}
\hline Kelompok & Reacting & Comparing/ Elaboration & Contemplating \\
\hline & terkandung dalam soal. & soal. & dengan tepat. \\
\hline $\begin{array}{c}\text { Rendah } \\
\text { (S-17 dan } \\
\text { S-30) }\end{array}$ & $\begin{array}{l}\text { Belum dapat menyebutkan } \\
\text { unsur yang diketahui dan } \\
\text { unsur yang ditanyakan da- } \\
\text { lam soal. }\end{array}$ & $\begin{array}{lr}\text { Belum dapat } \\
\text { menghubungkan masa- } \\
\text { lah yang ditanyakan } \\
\text { dengan masalah SPLTV } \\
\text { yang pernah dihada- } \\
\text { pinya, dan memberikan } \\
\text { alasan untuk } \\
\text { menyelesaikan soal. }\end{array}$ & $\begin{array}{l}\text { Belum } \\
\text { memberikan } \\
\text { kesimpulan } \\
\text { dengan tepat. }\end{array}$ \\
\hline
\end{tabular}

Berdasarkan Tabel 6, subjek pada kelompok Sedang dan Rendah belum melakukan tahapan kemampuan berpikir reflektif dengan tepat. Subjek pada kelompok Rendah belum melakukan tahap contemplating. Hal ini disebabkan belum mampu memahami aspek bahasa dan melakukan aspek prasyarat serta aspek terapan (Khasanah \& Sutama, 2015) yang terdapat pada soal. Berbeda dengan kelompok Sedang, subjek melakukan ketiga aspek, namun belum memberikan tindakan tepat untuk menjawab soal. Contoh jawaban siswa disajikan pada Gambar 2.

Berdasarkan soal dan hasil jawaban siswa yang telah dipaparkan, diperoleh bahwa KBRM siswa tergolong cukup. Hal ini dikarenakan, secara keseluruhan subjek mampu melakukan ketiga tahapan KBRM, namun ketidaktelitian dalam memahami dan melakukan aspek bahasa, prasyarat, dan terapan dalam soal, membuat sebagian siswa belum dapat menyelesaikan pertanyaan yang diajukan dengan benar.

\begin{tabular}{|c|c|}
\hline Ges $A=18000 \rightarrow$ ke pon $=$ & 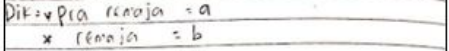 \\
\hline $\begin{array}{l}5 x+6 y+39=87.000 \\
5 x+6 y+3(18.000=87.00\end{array}$ & $\times$ Pendo $=c$ \\
\hline $\begin{array}{l}5 x+6 y+3(18.007=87.000 \\
5 x+6 y+54.000=87.000\end{array}$ & $\Rightarrow$ Pado hati pertoma: \\
\hline $\begin{aligned} 0 x+6 y=54.000 & =87.000 \\
5 x+6 y & =87.000-54 \cdot 000\end{aligned}$ & .) $a=5 \%$ \\
\hline $8 x+6 y=33 \cdot 000 \rightarrow y$ & $\begin{array}{l}\text {.) } b=6 \% \\
\Rightarrow c=9 \%\end{array}$ \\
\hline Qfer a be per 1 & $\Rightarrow$ Pada han kedio: \\
\hline $5 x+6 y+9 z=190 \cdot 00$ & $x a=5 \%$ \\
\hline $5 x+6 y+9(18.000)=65.000$ & \begin{tabular}{|l}
$x b=6 \%$ \\
$x<.6 \%$
\end{tabular} \\
\hline $\begin{aligned} 5 x+6 y+182000 & =175 \cdot 000 \\
5 x+6 y & =175 \cdot 00-152000\end{aligned}$ & $\Rightarrow c=6 \%=150.000$ \\
\hline $\begin{array}{l}x+6 y=43 \cdot 000 \rightarrow 5 \\
5 x+6 y=52000\end{array}$ & $\Rightarrow$ hati tros: $=0.7 .00 \mathrm{~b}$ \\
\hline El pen y 455 & 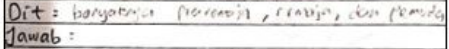 \\
\hline $5 x+6 y=33.000 \int_{x<}^{x 5} \mid 25 x+30 y=165.000$ & Hari pertomia $=195.000$ \\
\hline $25 x+30 y=15$ ap - & -) pro ramaja $=5 \%$ \\
\hline $\begin{array}{l}y=-0,000 \\
x=4.00 \text { no }\end{array}$ & $\frac{5}{100} \times 195.000=9.750$ \\
\hline bongt ny. praminge, $=50$ on $x=y=30 \cdot \mathrm{w}$ & -) $r(m(a)=1=6 \%$ \\
\hline $\begin{array}{l}\text { remege: } 50.00 \\
\text { piruse }=18.000\end{array}$ & $\frac{6}{100} \times 198.000=11.700$ \\
\hline 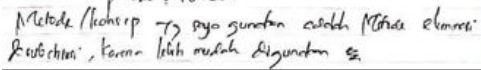 & $\begin{array}{l}\text { 1) } \text { Pemuda }=9 \% \\
\frac{9}{100} \times \lg 5.00=17.55 \%\end{array}$ \\
\hline
\end{tabular}


Gambar 2. Contoh Jawaban Siswa S12 dan S14 pada Soal Nomor 4

\section{Kesimpulan}

Kemampuan siswa dalam menyelesaikan soal cerita berkaitan erat dengan kemampuan berpikir reflektif matematis siswa. Siswa yang mampu menggunakan kemampuan berpikir reflektif matematis dengan baik akan mampu menjawab soal cerita yang diberikan. Berdasarkan hasil analisis jawaban dan wawancara menunjukkan bahwa berpikir reflektif baik comparing, comparing, dan contemplating digunakan siswa dalam menyelesaikan soal cerita, namun ketidaktelitian dalam memahami soal, menghubungkan, memberikan kesimpulan, hingga kegigihan, menyebabkan jawaban yang diberikan masih belum tepat.

\section{Daftar Pustaka}

Arifin, Z. (2016). Evaluasi Pembelajaran. Bandung: PT. Remaja Rosdakarya.

Khasanah, U., \& Sutama. (2015). Kesulitan Menyelesaikan Soal Cerita Matematika pada Siswa SMP. Prosiding Seminar Nasional Pendidikan Matematika UMS 2015, 79-89.

Nuriadin, I. (2015). Peningkatan Kemampuan Generalisasi dan Berpikir Reflektif Matematis serta Self-development Peserta Didik Melalui Strategi Pembelajaran Knowledge Sharing. Universitas Pendidikan Indonesia. Tidak Dipublikasikan.

Putri, A. S., \& Mampouw, H. L. (2018). Profil Berpikir Reflektif Siswa dalam Menyelesaikan Soal Tipe-tipe Perkalian Ditinjau dari Perbedaan Kemampuan Matematika dan Gender. Math Didactic: Jurnal Pendidikan Matematika, 4(1), 34-46.

Salido, A. (2019). Analisis Strategi Berpikir Reflektif Matematis Siswa SMA dalam Pemecahan Masalah Matematis. Universitas Pendidikan Indonesia. Tidak Dipublikasikan.

Sihaloho, R., \& Zulkarnaen, R. (2019). Studi Kasus Kemampuan Berpikir Reflektif Matematis Siswa SMA. Prosiding Seminar Nasional Matematika Dan Pendidikan Matematika, (3), 736-741. Karawang: 12 Desember 2019.

Suharna, H. (2018). Teori Berpikir Reflektif. Yogyakarta: Deepublish.

Zulkarnaen, R. (2017). Kesalahan Siswa dalam Menyelesaikan Sistem Persamanan Linier dalam Bentuk Soal Cerita. Prosiding Seminar Nasional Matematika Dan Pendidikan Matematika STKIP Siliwangi, 54-58. 